\title{
THE EVOLUTION OF THE WORKFORCE IN AGRICULTURE IN ROMANIA
}

\author{
MAVRODIN Cristina ${ }^{1}$ \\ Doctorate Student, Bucharest University of Economic Studies, Romania, mavrodincristina75@gmail.com
}

\begin{abstract}
The labor force in agriculture, especially in a considerably rural society and economy, as is the case of Romania, constitutes an important subject of study, based on the measurement and analysis of the main indicators. The purpose of the present paper is to analyze the main indicators revealing the employment in agriculture, the evolution of this sector in the last decades and the potential problems created by the decrease of the labor force in agriculture. Data analyzed in this paper are extracted mainly from the European Union Open Data Portal and from the World Bank, covering a long period of time, more precisely 1991-2018. The data refer to the main indicators regarding the employment in agriculture in Romania in absolute figures and as a percent of the total employment, as well as to other variables relevant for the current research. Employment in agriculture is an important indicator for acknowledging the trend of the work force in this sector.

The statistical processing of the raw data clearly indicates that the employment in agriculture has decreased constantly and considerably since 1991, both in absolute figures and as a percent of total employment, although Romania remains the country of the European Union with the biggest number of employees involved in agricultural or agriculture-related productive activities. The size of the decrease varies from year to year, yet it clearly indicates a significant decline, requiring a comprehensive investigation and proper measures taken by the responsible official authorities.
\end{abstract}

KEY WORDS: Agriculture, workforce, employment, rural

\section{INTRODUCTION}

In a country like Romania, in which almost half of the population continues to live in the rural areas and in which agriculture remains the only lucrative activity for a big number of its inhabitants, the quantity and quality of the rural working force is of extreme importance.

The most recent data provided by the Romanian National Institute of Statistics (NIS, 2019) indicate that, at the end of 2018 , almost $44 \%$ of the population in Romania lived in the rural area, being mainly dependent on the subsistence agriculture. Although the entrepreneurship and non-agricultural businesses in the rural area are highly encouraged through various governmental programs and European funds, the number of companies established in the countryside remains relatively small (Bădescu \& Cristea, 2011, p. 54) and a big part of the rural population remains involved in agricultural and agriculture-related activities.

Furthermore, although the contribution of agriculture to the structure of the Gross Domestic Product (GDP) has decreased substantially in the last decades, from $23 \%$ in 1990 to $12.1 \%$ in 2000 (Dachin, 2011, p. 155), the productive activities in the field of agriculture, forestry and fishing continued to bring a contribution of $4.4 \%$ to the GDP in 2018 (NIS, 2019).

Given all these elements, the evolution of the workforce in agriculture in Romania is both a significant and topical subject of analysis, as it clearly indicates a downward trend and requires a thorough inquiry into the causes and consequences of this phenomenon.

Using official data provided by Romanian National Institute of Statistics (NIS), European Union Open Data Portal (Eurostat) and World Bank (WB), the main objective of the current paper is to present and analyze the indicators related to the employment in agriculture, the evolution of this sector in the last decades and the potential problems created by the decrease of the labor force in this field.

Although the theme is a very important and actual one, it is also a sensitive one, therefore there are not many up-to-date analyses and presentations of the evolution of the workforce in agriculture in Romania.

\section{THE EVOLUTION OF THE RURAL POPULATION IN ROMANIA DURING 1991-2018}

The number of the population living in the rural area is an indicator of a country's degree of rurality / urbanization, and from this point of view Romania remains a considerably rural country, with $43.64 \%$ of the population living in the countryside in 2018, although the number decreased constantly, yet not significantly, since 1990. As indicated in Figure 1, the total of population living in the rural area decreased by almost 10\% during 1992-2018, from 10,665,242 inhabitants to $9,693,472$ inhabitants on January 1st, 2019 (NIS, 2019). 


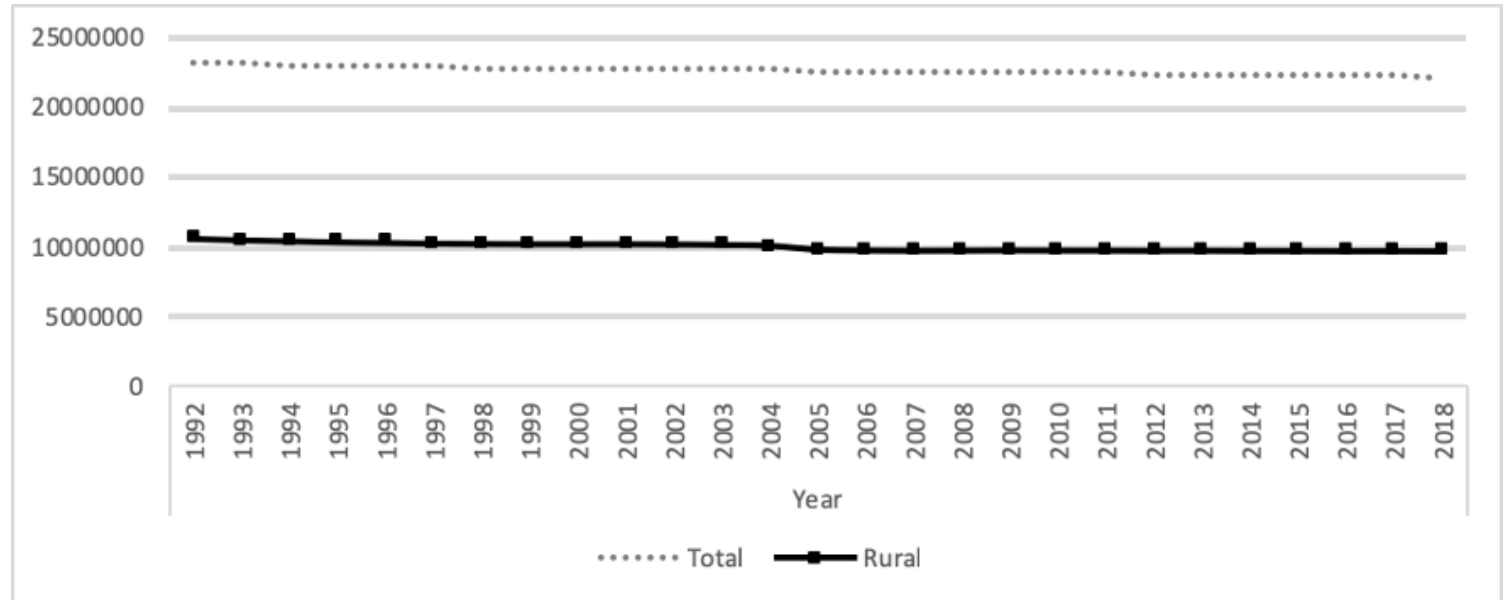

Figure 1. Total of population in Romania, based on residency, at January $1^{\text {st }}, 2019$ Source: own processing on the basis of the data provided by NIS, 2019.

Compared to the downward trend registered in the same period at the level of the total population, the decrease of the number of individuals living in the rural areas is almost double, indicating a significant migratory phenomenon.

Although at the level of the European Union (EU) the degree of rurality fluctuated, with a slight increase, in the last seven years, from $26.3 \%$ in 2010 to $27.3 \%$ in 2017 , mainly due to the integration of Croatia and as a result of the tendency of Europeans to leave city areas in favor of the countryside (EC, 2017), in the least developed member countries, including Romania, the trend is reversed, as indicated in Figure 2.

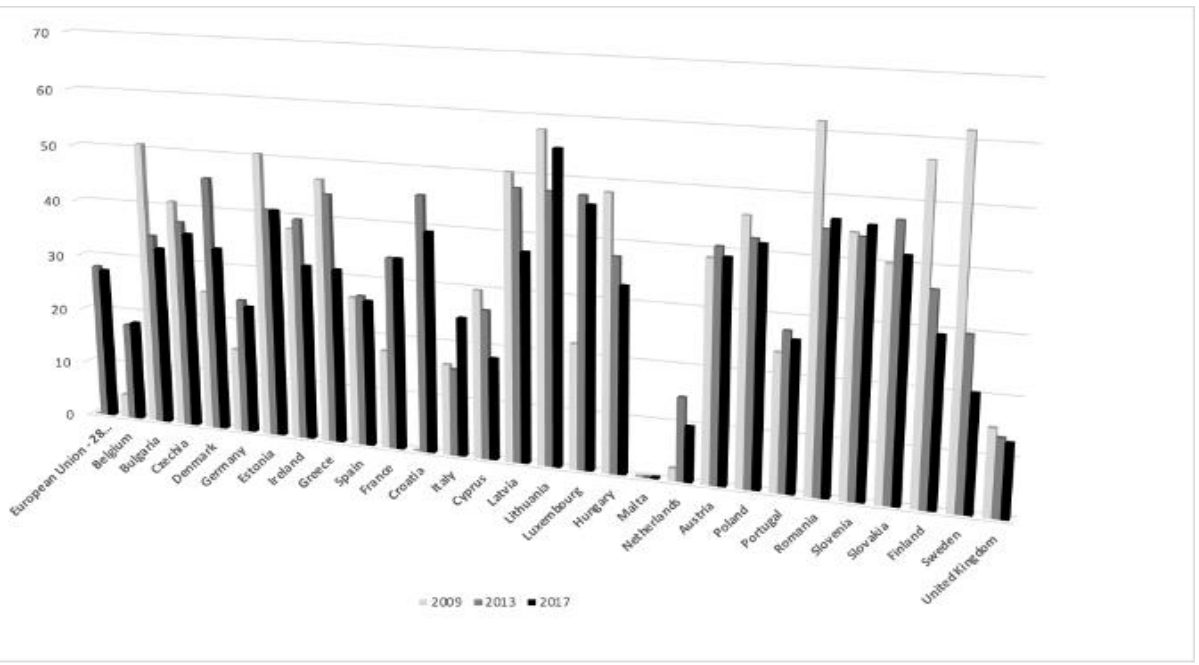

Figure 2. Evolution of rural population (\% of total) in EU, during 2009-2017

Source: own processing on the basis of the data provided by Eurostat (2019).

The relatively high degree of rurality in many countries of the EU, including Romania, brings into attention serious problems, such as the decline of the rural economy and a lower level of employment, which inevitably leads to a bigger number of individuals living at risk of poverty or social exclusion (Eurostat, 2018). Therefore, the unemployment risk in rural areas is significant because it triggers the deterioration of the inhabitants' quality of life. Moreover, such problems, coupled with several other concerning trends, such as the pronounced ageing of the rural population might imperil an important sector of the economy.

\section{THE EVOLUTION OF EMPLOYMENT IN AGRICULTURE IN ROMANIA DURING 1991-2018}

The number of employees involved in agriculture in Romania recorded a considerable fluctuation during 1991-2018, both in absolute figures and as a percent of the total workforce. Overall, the employment rate decreased from $36.2 \%$ in 1991 to only $22.28 \%$ of total employment in 2018 (World Bank, 2019), indicating a definite decline of the rural economy and, implicitly, of the contribution of agriculture to the national GDP from $23 \%$ in 1990 to only $4.4 \%$ to the GDP in 2018 (NIS, 2019).

As indicated by most recent data provided by the World Bank (2019), the share of the employment in agriculture in Romania 
matches the share registered at the world level (with $25.96 \%$ of the total employment engaged in agriculture), yet it is far bigger than the employment in agriculture as a percent of total employment registered at the level of the European Union, which barely reaches $4.1 \%$. The comparison between EU, Romania and World is indicated in Figure 3.

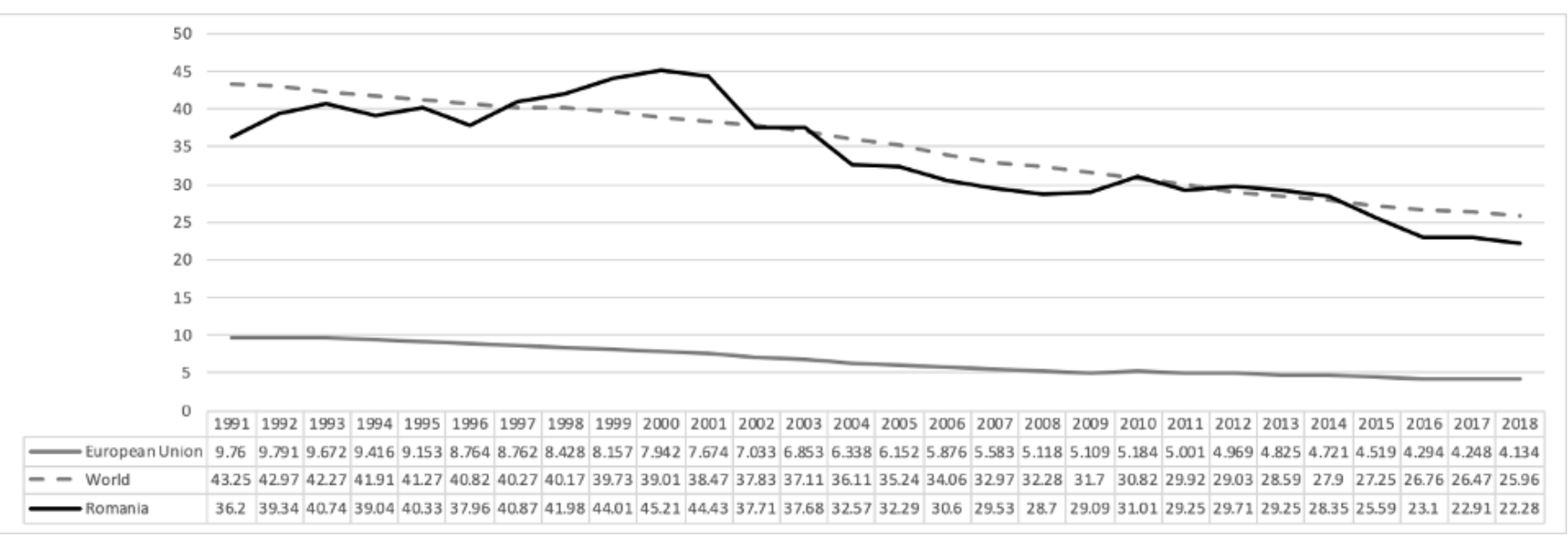

Figure 3. Employment in agriculture (\% of total employment) during 1991-2018

Source: own processing on the basis of the data provided by WB (2019).

The number of employees in agriculture decreased worldwide in the last decades, yet the rate of the decline was bigger at the level of the EU, where the agricultural workforce more than halved during the analyzed period. The causes of such a big downturn are complex and various, yet one could certainly mention the early adoption and on a large scale of technology, as well as the utilization of more productive practices, with the resulting productivity increment without the need for a big workforce (Roser, 2019).

In terms of sex distribution, although at present the share of male employees as a percent of total male employment is slightly higher that the share of female employees as a percent of total female employment, it should be mentioned that the decrease of the female workforce during 1991-2018 is bigger than that of the male workforce involved in agricultural and agriculture-related activities and services. As indicated in Figure 4, the female employment in agriculture declined from $40.27 \%$ in 1991 to $21.46 \%$ in 2018 , while the male employment in agriculture contracted only by almost 10 percentage points, from $32.61 \%$ in 1991 to $22.9 \%$ in 2018 (World Bank, 2019).

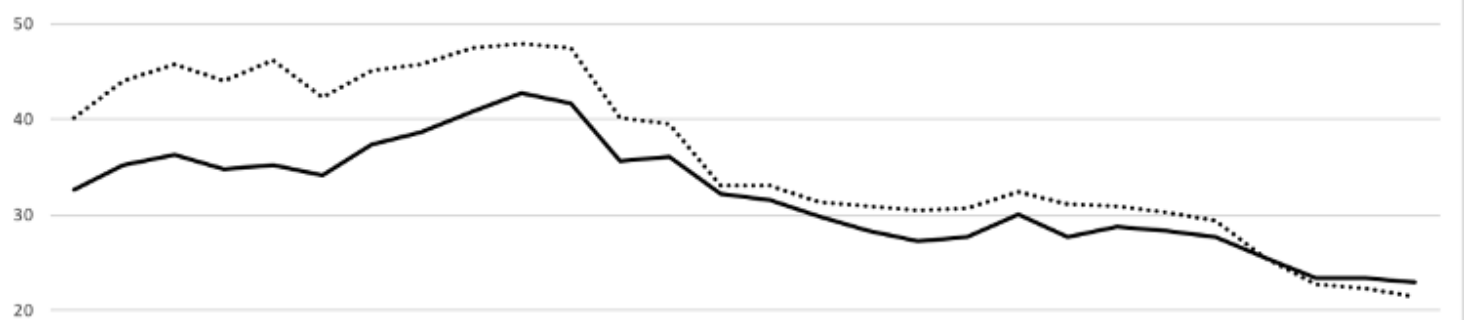

10

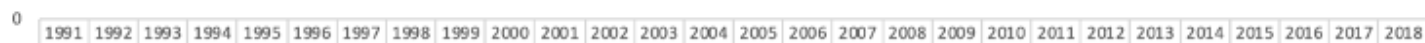

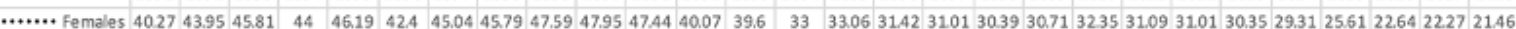

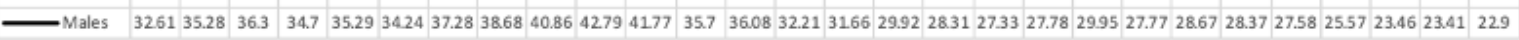

Figure 4. Employment in agriculture, male and female (\% of total male and female employment) during $1991-2018$

Source: own processing on the basis of the data provided by WB (2019).

Although in Romania the shrinkage of the employment in agriculture is slightly smaller than the reduction registered globally, the decrease is nevertheless significant, given the fact that the level of technological endowment of Romanian agriculture is much lower than the EU average (Profit.ro, 2017), and the productivity and performance are still largely dependent on the workforce.
The evolution of the workforce involved in agricultural activities in Romania did not follow a steady decrease. In the last years, for instance, as indicated in Figure 5, both the number of employees in crop and animal production, hunting and related service activities, as well as the number of individuals working in the forestry and logging field registered a fluctuating trend, with the biggest declines in the fourth 
quarter of 2016 for forestry and logging and the first quarter of 2017 for crop and animal production.

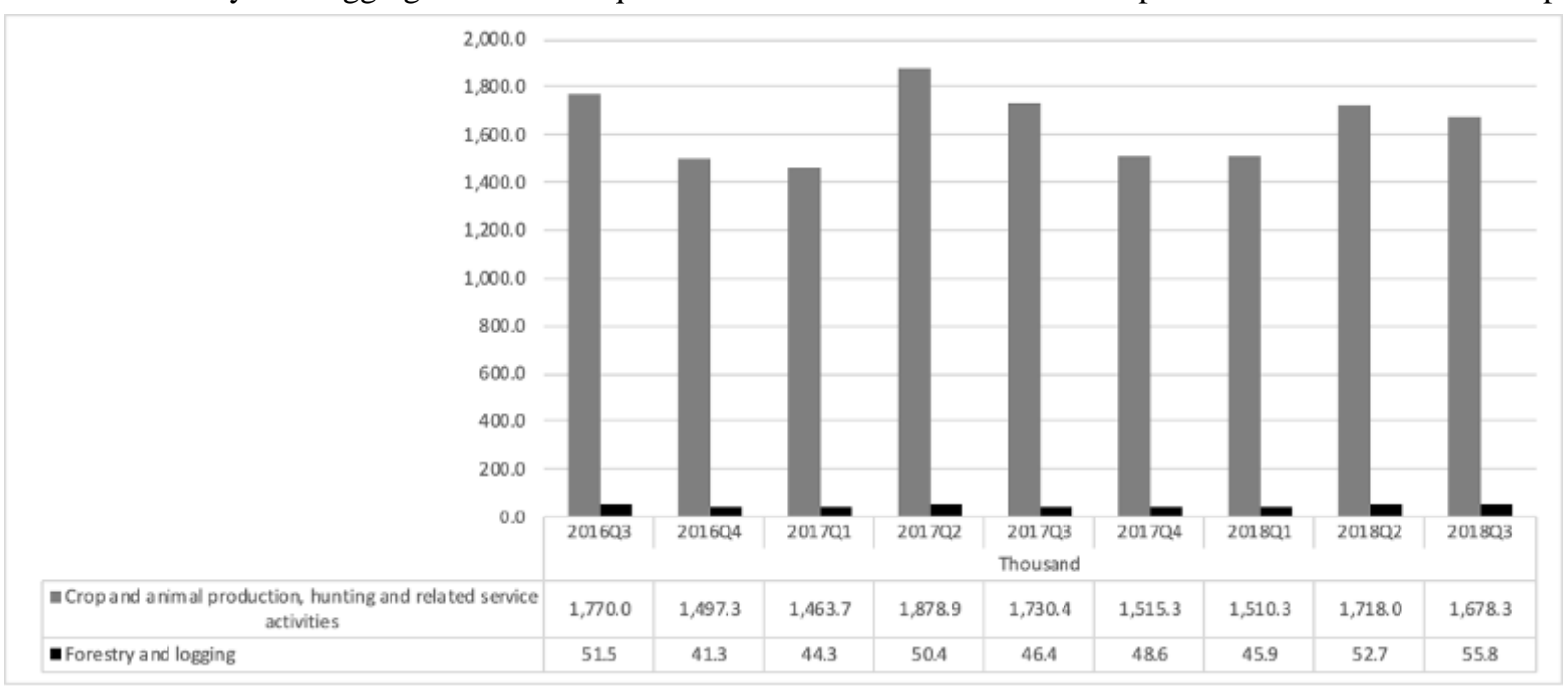

Figure 5. Number of employees in agriculture in Romania, in 2016-2018

Source: own processing on the basis of the data provided by Eurostat (2019).

In the last years, the highest number of individuals involved in crop and animal production and related service activities was recorded in the second quarter of 2017, with $1,878,900$ employees, while in the third quarter of 2018 the forestry and logging field had the highest number of employees, namely 55,800. A possible explanation for these oscillations in the number of employees is the collection of European funds either in the form of investments or in the form of subsidies, as well as the seasonal activities specific to agriculture that require a bigger or a smaller number of laborers.
Although in the last period the employees in agriculture registered an overall decrease both in absolute and relative numbers (as a percent of the total number of employees), Romania still occupies the first position among the members of the EU in terms of people activating in the agricultural field. As indicated in Figure 6, the newest non-Euro member countries of the EU had the highest number of employees involved in crop and animal production and hunting and related service activities in 2016-2018, with Romania and Poland occupying the first positions.

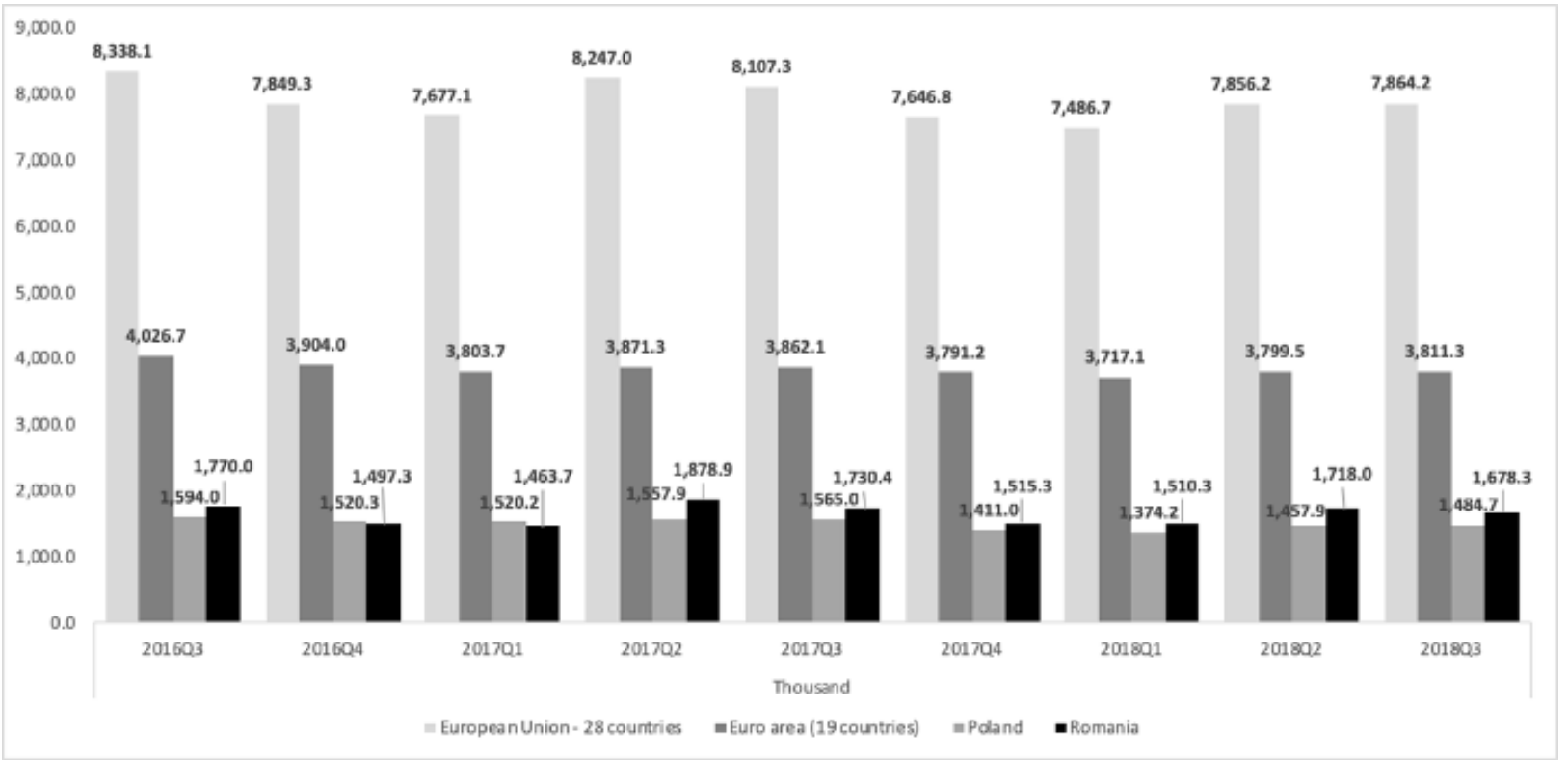

Figure 6. Number of employees in crop and animal production, hunting and related service activities in EU in $2016-2018$

Source: own processing on the basis of the data provided by Eurostat (2019).

At first sight, the evolution of the workforce in agriculture in the last years performed better than the workforce involved in other types of activities, especially in urban regions. For instance, in 2013 the unemployment rate in urban areas was generally higher than in rural regions, namely $8.9 \%$ in urban versus $5.3 \%$ unemployment rate in rural areas, while the longterm unemployment in the same year registered a value of
$49.1 \%$ in urban areas and $40.8 \%$ in rural regions (Iorga, 2017, p. 184). Nevertheless, in 2017 , the trend was reversed, with an unemployment rate of $5.4 \%$ in the rural areas compared to $4.5 \%$ in the urban areas, while the long-term unemployment registered a similar value, of $41,5 \%$ in urban areas compared to $41.4 \%$ in rural regions (NIS, 2018). Although the unemployment rate in the rural areas does not refer only to 
population that might be involved in agricultural activities and services, the indicator is nevertheless informative and useful in evaluating the level of rural development.

Nonetheless, specific to countries with developing regions and a lower level of technology adoption in agriculture, many workers are not registered in the formal employment system, but are either self-employed or involved in unpaid family work, mainly in subsistence farming (FAO, 2012, p. 18). This situation is also confirmed from Romania, where a considerable part of the labor force is non-employed formally, but working in their own household for own consumption, as indicated

in Figure

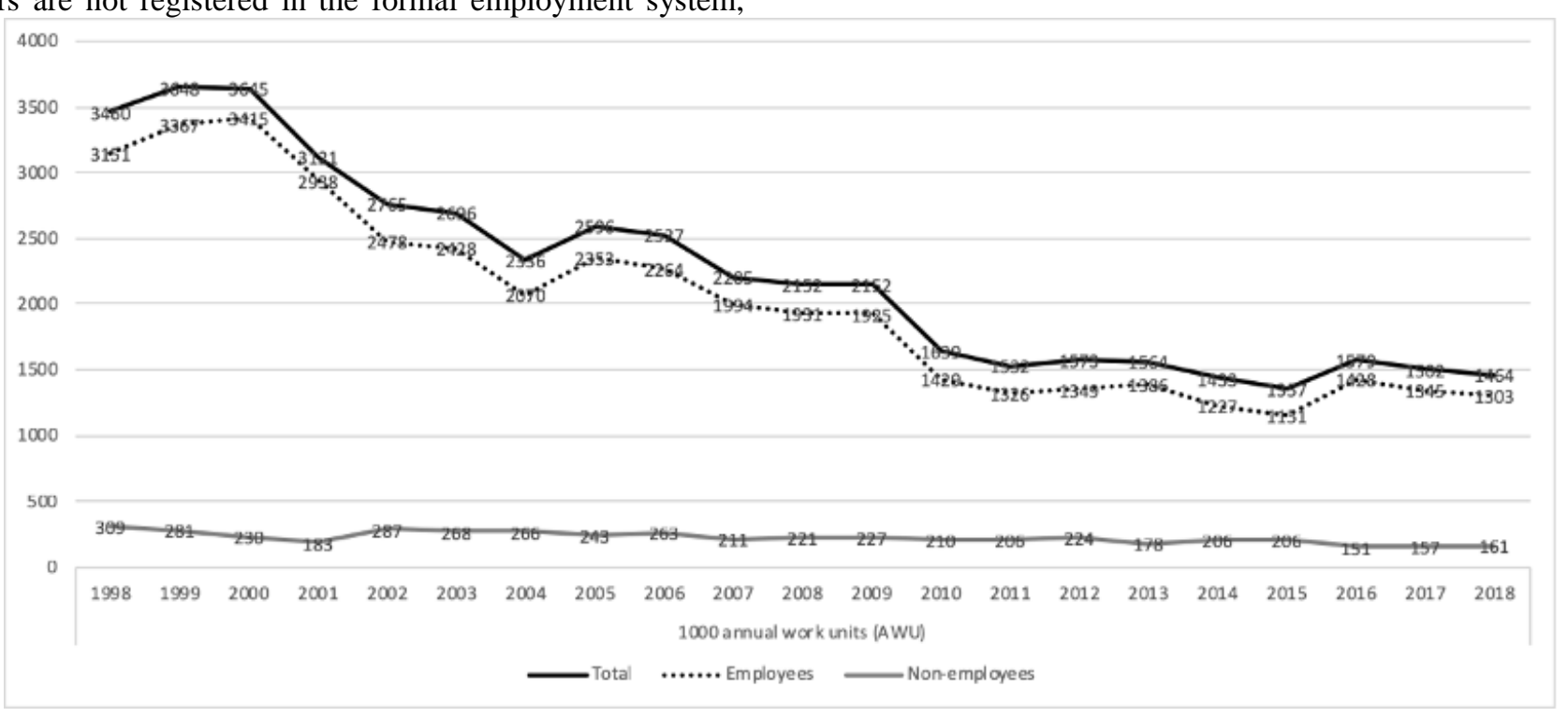

Figure 7. Labor force volume in agriculture in Romania, in 1998-2018

Source: own processing on the basis of the data provided by NIS (2019).

The volume of labor force in agriculture, expressed in thousands of annual work units (AWU), indicate that the total number of days worked in agriculture annually was divided between employed and unemployed workers who performed various activities, with a significant percent of the latter in the last period of time.

\section{CONCLUSIONS}

The main conclusion derived from the presentation of the evolution of the workforce in agriculture in Romania is that, in the last decades, the number of persons involved in agricultural and agriculture-related productive activities declined constantly, a trend also registered worldwide, especially at the level of the European Union. Although such a descending trend might be an indicator of the increase of the degree of urbanization or, more importantly, of the adoption of high technology in agriculture, in Romania the figures are rather alarming, pointing out that an important economic activity is losing its workforce.

Although almost $44 \%$ of the Romanian population live in rural areas, only approximately $22 \%$ of the total workforce is employed in agriculture, meaning that a big part of the rural population lost its main traditional activity, with potentially dramatic consequences both at micro-level (the individual) and macro-level (the society). Moreover, the decline is more evident among the females than among the males, which puts an already vulnerable category of persons at risk of social exclusion and even extreme poverty.

The factors responsible for this evolution are both varied and complex and exceed the scope of the current paper, yet it is worth mentioning here that agriculture still has a $4.4 \%$ contribution to the GDP and deserves more attention from authorities and researchers alike.

\section{REFERENCES}

1. Bădescu I.; Cristea D. (2011) Elemente pentru un Dicționar de sociologie rurală: Concepte - Teme - Teorii. București: Editura Mica Valahie.

2. Dachin A. (2011) Contribuții ale agriculturii la fluctuațiile economice în România. Economie teoretică și aplicată, Vol. XVIII, 1(554), 154-165.

3. EC (European Commission). (2017) Statistics on rural areas in the EU, 2017. Retrieved from https://ec.europa.eu/eurostat/statisticsexplained/index.php/Statistics on rural areas in the EU.

4. Eurostat (2018) Eurostat Regional Yearbook 2018 Edition. Luxembourg: Publications Office of the European Union.

5. Eurostat (2019). Eurostat Database, European Union. Retrieved

from https://ec.europa.eu/eurostat/web/main/home.

6. FAO (2012) FAO Statistical Yearbook 2012, World Food and Agriculture. Rome: Food and Agriculture Organization of the United Nations.

7. Iorga A. M. (2017). Characteristics of the Romanian Agriculture Workforce. Scientific Papers Series Management, Economic Engineering in Agriculture and Rural Development, 17(2). Retrieved from http://managementjournal.usamv.ro/pdf/vol.17_2/Art25.pd f.

8. NIS (National Institute of Statistics). (2017). Forța de muncă în România. Ocupare și Şomaj în anul 2017. Retrieved from http://www.insse.ro/cms/sites/default/files/field/publicatii/f orta_de_munca_in_romania_ocupare_si_somaj_2017.pdf.

9. NIS (National Institute of Statistics). (2019) Tempo-Online Database. Retrieved from http.//statistici.insse.ro.8077/tempoonline/\#/pages/tables/insse-table. 
10. Profit.ro. (2017). Analiză: România are 6-a cea mai mare suprafață agricolă utilizată dintre țările UE, dar o producție slabă din lipsă de bani, instalații și fermieri pregătiți. March $7^{\text {th }}, 2017$. Retrieved from: https://bit.ly/2Ve4K6N.
11. Roser M. (2019) Employment in Agriculture. OurWorldInData.org. Retrieved from https://ourworldindata.org/employment-in-agriculture.

12. World Bank. (2019). World Bank Open Data. Retrieved from

https://data.worldbank.org/indicator/SL.AGR.EMPL.ZS. 